\title{
Characterization and Antibacterial Activity of Bacteriocin Producing Lactobacillus Isolated from Raw Cattle Milk Sample
}

\author{
A. Mohankumar (Correponding author) \\ Department of Zoology, Chikkanna Government Arts College \\ Tirupur-641 602, Tamilnadu, India \\ E-mail: moniver@satyam.net.in \\ N. Murugalatha \\ Department of Microbiology, Hindusthan College of Arts \& Science \\ Coimbatore- 614 028, Tamilnadu, India
}

Received: April 15, 2011 Accepted: April 30, 2011 doi:10.5539/ijb.v3n3p128

\begin{abstract}
The intent of the study is to determine the antimicrobial activity of Lactobacillus producing bacteriocin isolated from raw milk of cattle's like cow, buffalo and goat and to characterize the bacteriocin. Hundred Lactobacillus isolates (50 isolates from cow, 22 isolates from buffalo and 28 isolates from goat) based upon the distinct morphology were isolated from the samples and identified as Lactobacilli according to phenotypic characteristics. Bacteriocin producing organisms were screened by Agar spot assay test. Ten strains were able to produce bacteriocin whose antibacterial activity was analyzed by agar well diffusion assay test against indicator organisms and pathogenic organisms. Bacillus mycoides, Staphylococcus aureus, Streptococcus faecalis, Klebsiella pnuemoniae and Proteus vulgaris were inhibited by the isolates. Bacillus amyloliquifaciens, Bacillus cereus, Salmonella typhi and Pseudomonas aeruginosa, were resistant to the isolates producing antibacterial substances. The antibacterial protein bacteriocin was characterized based on the sensitivity to heat, different $\mathrm{pH}$ values, acid neutralization test, sensitivity to chloroform, $\mathrm{NaCl}$ and incubation period. Lactobacilli from raw milk samples that inhibited certain pathogenic organisms by producing bacteriocin may be beneficial for a probiotic culture to be triumphant in colonizing and to contend with pathogens.
\end{abstract}

Keywords: Raw milk, Lactic acid bacteria, Antibacterial activity and bacteriocin characterization

\section{Introduction}

Lactic acid bacteria are a group of Gram-positive bacteria united by a constellation of morphological, metabolic, physiological characteristics (Coeuret et al., 2003). They produce lactic acid either through homofermentative or heterofermentative pathway and are wide spread in nature and also found in human digestive system. Lactobacilli are considered especially as beneficial bacteria because they have their ability to break down proteins, carbohydrates and fats in food and help in absorption of necessary elements and nutrients such as minerals, aminoacids and vitamins required for the survival of humans and other animals. Lactic acid bacteria exert a strong antagonistic activity against many food-contaminating microorganisms as a result of the production of organic acids, hydrogen peroxide, diacetyl, inhibitory enzymes and bacteriocins (Piard and Desmazeaud, 1991). Lactobacillus exerts a positive documentation in the prevention and treatment of gastrointestinal disorders. Although anti-microbial agents are generally effective at eradicating these infections, there is a high incidence of recurrence. Certain Lactobacilli synthesize antimicrobial compounds that are related to the bacteriocin family (Jack et al., 1995; Klaenhammer, 1993). Antimicrobial substances produced by Lactic acid bacteria (LAB) are used in association with selective insensitive starter to inhibit competitive microflora (Scannell et al., 2000). The term bacteriocin refers to protein of the colicin type, characterized by lethal biosynthesis, intraspecific activity and absorption to specific receptors and the bacteriocins produced by Lactobacillus fit closely to the classical colicin model (Tagg et al., 1976). Lactobacilli produce many different bacteriocins of similar activity and are usually predominant species.

This study was focused on isolation and characterization of bacteriocin-producing Lactobacillus from cattle milk like cow, buffalo, goat and its inhibitory nature against common human pathogens. 


\section{Materials and Methods}

\subsection{Isolation of Lactic acid bacteria}

Raw unpasteurized hundred milk samples of Cow, Buffalo and Goat were collected from the local area of Coimbatore during lactation period under aseptic conditions in a sterile screw cap tubes, processed within three hours and used for further studies.

Milk samples were serially diluted in peptone medium and incubated at $23^{\circ} \mathrm{C}$ for $30 \mathrm{~min}$ before plating by which $50 \%$ of recovery of LAB was increased. Diluted samples were plated onto De Man Rogosa Sharpe (MRS) medium for Lactobacillus isolation and incubated at $37^{\circ} \mathrm{C}$ for $48-72 \mathrm{hrs} .100$ numbers of well-isolated colonies with typical characteristics namely pure white, small $(2-3 \mathrm{~mm}$ diameter) with entire margins were picked from each plate and transferred to MRS broth. The isolates were designated as CWL (Cow), BFL (Buffalo) and GAL (Goat).

\subsection{Identification of the Bacterial strains}

Further identification of the Lactobacilli was performed according to their morphological, cultural, physiological and biochemical characteristics (Sharpe, 1979; Kandler and Weiss, 1986): Gram reaction, production of catalase, carbohydrate fermentation patterns, growth at $15^{\circ} \mathrm{C}$ and $45^{\circ} \mathrm{C}$ in the lactobacilli De Mann Rogosa and Sharpe (MRS) broth as described by Bergey's Manual of Systematic Bacteriology (Kandler and Weiss, 1986), methyl red and Voges-Proskauer test in MR-VP medium, nitrate reduction in nitrate broth, indole production in Tryptone broth. Purified cultures were maintained at $-20^{\circ} \mathrm{C}$ in MRS broth with $10 \%$ glycerol and enriched in MRS broth incubated at $37^{\circ} \mathrm{C}$ for $24 \mathrm{hrs}$. The identified genus Lactobacillus was further classified to the species level based on their ability to ferment sugars (Singh. And Rakesh Roshan Sharma, 2009).

\subsection{Detection of Inhibitory activity}

\subsubsection{Agar Spot Assay Test}

100 Lactic acid bacterial isolates were cultured in $5 \mathrm{ml}$ of MRS broth at $30^{\circ} \mathrm{C}$ for $16 \mathrm{hrs}$. Aliquots $(2 \mu \mathrm{l})$ of the culture were spotted onto agar plates containing $10 \mathrm{ml}$ of MRS medium. After $18 \mathrm{hrs}$ at $30^{\circ} \mathrm{C}$, the plates were overlaid with $5 \mathrm{ml}$ of the appropriate soft agar (1\% agar) inoculated with the cell suspension of the indicator strain Lactobacillus acidophilus at a final concentration of $10{ }^{5} \mathrm{CFU} / \mathrm{ml}$ (Kilic et al., 1996). The plates were incubated at $37^{\circ} \mathrm{C}$ for $24-72 \mathrm{hrs}$, depending on the growth of the indicator strain and the appearance of inhibitory zones were observed. Inhibition was scored positive if the zone was wider than $2 \mathrm{~mm}$ in diameter.

\subsubsection{Agar-Well Diffusion Assay}

The strains that were selected as potential bacteriocin producers were grown in MRS broth at $37^{\circ} \mathrm{C}$ for $48 \mathrm{hrs}$. Cells were separated by centrifugation at $5000 \mathrm{rpm}$ for $10 \mathrm{~min}$ at room temperature. Around $6 \mathrm{~mm}$ diameter wells were made on preinoculated agar media and each well was inoculated with $100 \mu$ l of culture supernatant of bacteriocin producing Lactobacillus strains after neutralization with $\mathrm{NaOH}$ (Toba et al., 1991). Inhibitory activity was performed against certain Gram positive and Gram negative organisms: Bacillus amyloliquifaciens (MTCC 1270), Bacillus cereus (MTCC 1272), Bacillus mycoides (MTCC 645), Lactobacillus acidophilus (MTCC 447), Lactobacillus delbrueckii sub sp. lactis (MTCC 911), Lactococcus lactis sub sp. lactis (MTCC 440), Streptococcus faecalis (MTCC 459), Staphylococcus aureus (MTCC 740), Klebsiella pneumoniae (MTCC 3384), Proteus vulgaris (MTCC 744), Pseudomonas aeruginosa (MTCC 647) and Salmonella typhi (MTCC 531). Inhibition zones around the wells were measured and recorded.

\subsection{Characterization of Bacteriocin}

\subsubsection{Sensitivity to heat}

$100 \mu 1$ of culture supernatant was heated for $10 \mathrm{~min}$ at $60^{\circ} \mathrm{C}, 70^{\circ} \mathrm{C}, 80^{\circ} \mathrm{C}$ and $90^{\circ} \mathrm{C}$. The agar spot assay test was performed to detect residual activity. The resistant culture supernatants were further heated for 10,30 and 60 min at $100^{\circ} \mathrm{C}$ and the residual activity was assayed (Larsen et al., 1993).

\subsubsection{Sensitivity to different $\mathrm{pH}$ values}

The $\mathrm{pH}$ of culture supernatants was adjusted to 3.0, 4.5, 7.0 and 9.0 and then kept at room temperature for $4 \mathrm{hrs}$. Residual activity was determined by the agar-spot method as described (Larsen et al., 1993).

\subsubsection{Acid neutralization test}

This test was performed by agar well diffusion assay (Alpay et al., 1991). In addition to $100 \mu 1$ of supernatants buffered with $\mathrm{NaOH}$ to $\mathrm{pH} 7.0,75 \mu \mathrm{l}$ of Lactobacillus suspension and $25 \mu 1$ of $10 \% \mathrm{CaCO}_{3}$ solution were mixed and placed into the well. The original culture supernatants were used as control samples. When the inhibition 
zone was determined around the wells of the control and buffered samples, the inhibitory effect was assumed to be due to bacteriocin or $\mathrm{H}_{2} \mathrm{O}_{2}$ (Diaz et al., 1993).

\subsubsection{Sensitivity to chloroform}

The culture supernatant was mixed with an equal volume of chloroform and kept at room temperature for $4 \mathrm{hrs}$ before antimicrobial activity testing (Diaz et al., 1993).

\subsubsection{Effect of $\mathrm{NaCl}$ on bacteriocin production}

MRS broth with $1 \%, 3 \%, 4 \% \mathrm{NaCl}$ and without $\mathrm{NaCl}$ was sterilized by autoclaving and were inoculated with $10 \%$ of the overnight bacteriocin producing culture and incubated at $37^{\circ} \mathrm{C}$ for $24 \mathrm{hrs}$. Bacteriocin activity was assayed by inoculating the culture supernatant against indicator organism (Alpay et al., 2003).

\subsubsection{Effect of incubation period on bacteriocin production}

Active cultures of producer organisms $(1 \% \mathrm{v} / \mathrm{v})$ were inoculated in $100 \mathrm{ml}$ aliquots of sterile composed media. Inoculated flasks were incubated at $37^{\circ} \mathrm{C}$ for $15,24,48$ and $72 \mathrm{hrs}$ and at the end of each incubation period, bacteriocin activity was observed by inoculating culture supernatant against indicator organism (Lade et al., 2006).

\subsubsection{Effect of different concentrations of carbon and nitrogen source on bacteriocin production}

The effect of different concentrations of medium ingredients on bacteriocin production was evaluated using composed MRS medium. The carbon sources studied were glucose $(1 \%-3 \%)$ and lactose $(1 \%-3 \%)$ while nitrogen sources were tryptone $(1 \%-3 \%)$, peptone $(1 \%-3 \%)$ and yeast extract $(0.5 \%-2 \%)$ (Lade et al., 2006).

\section{Results}

100 Lactobacillus colonies from milk samples (50 from cow milk, 22 from buffalo milk and 28 from goat milk) with typical characteristics namely pure white, small (2-3 mm diameter) with entire margins were picked from each plate and transferred to MRS broth which was then subjected to classification onto the genera Lactobacillus based on morphological and biochemical characters.

All strains reacted positively to gram staining under a light microscope. Lactobacilli are generally long rods some times they are short rods, coccoid. It happens that cells of coccoid form strains were not able to show growth at $45^{\circ} \mathrm{C}$. Few isolates from buffalo and goat were able to utilize citrate indicating the passage of citrate into a cell with aid of citrate permease. Lactobacillus donot possess flagella and donot create endospores, nitrates are not reduced, gelatin is not liquefied, indole is not produced, acidic and non acidic end products are not produced and are catalase negative. The isolates were found to be homofermentative that produce lactic acid from glucose, lactose and mannitol (Tables 1, $2 \& 3$ ).

The identified genus Lactobacillus was further classified to the species level. Strains were able to ferment sugars at different percentages which were much significant for identification of the species. Among ten different sugars sucrose was fermented by all the isolated strains. Trehalose was utilized by $94 \%$ of the isolates and $60-80 \%$ of the isolates fermented all other sugars. The differentiating characters of Lactobacillus are given in Tables 4, 5 and 6 and based on the above characters it was concluded that Lactobacillus casei, Lactobacillus fermentum, Lactobacillus lactis were found commonly in all cattle's milk. Lactobacillus plantarum was specifically found in cow milk. Lactobacillus brevis was found in buffalo milk. Lactobacillus delbrueckii was found in goat mik. Lactobacillus lactis was dominating the Lactobacillus casei and Lactobacillus fermentum in the cow milk sample. Similarly the same species was dominating the Lactobacillus casei, Lactobacillus delbrueckii and Lactobacillus fermentum in case of a buffalo and goat milk sample.

\subsection{Bacteriocin Assay}

\subsubsection{Agar Spot Assay Test}

The culture supernatants obtained from a total of 100 Lactobacilli isolates of all the milk samples were tested for antibacterial activity against the same group of lactobacilli. Ten isolates have shown clear zone of inhibition against the indicator organism and they were selected as potential bacteriocin producers. 5 isolates from cow milk sample, 2 isolates from buffalo and 3 isolates from goat milk sample were able to show inhibitory action against the indicator strain.

\subsubsection{Agar Well Diffusion Assay}

The culture supernatant obtained from ten bacteriocin producer strains were tested for antibacterial activity against certain Gram positive and Gram negative bacteria. Bacteriocins obtained from the isolates showed inhibitory activity against Bacillus mycoides, Streptococcus faecalis, Staphylococcus aureus and Proteus 
vulgaris among the sensitive bacteria tested. Bacillus amyloliquifaciens, Bacillus cereus, Pseudomonas aeruginosa, and Salmonella typhi were resistant to bacteriocin producers. The resistant activity varied with each strain. The degree of inhibition was designated as very strong inhibition $(15-18 \mathrm{~mm})$, strong inhibition $(10-14 \mathrm{~mm})$, moderate inhibition $(6-9 \mathrm{~mm})$ and no inhibition. BFLI and GAL2 showed very strong activity against Bacillus mycoides with the zone of inhibition of $15-18 \mathrm{~mm}$ in diameter. Staphylococcus aureus was moderately inhibited by BFL2, GAL2 and GAL3 with a zone of inhibition $6-9 \mathrm{~mm}$ in diameter and very strongly inhibited by CWL1, CWL17, CWL25, CWL29, BFL1 and GAL1. Streptococcus faecalis and Proteus vulgaris were inhibited at a higher range by the bacteriocin isolates when compared to other strains. The two strains BFL1 and GAL1 showed very strong activity against Klebsiella pneumoniae (Table 7).

\subsection{Characterization of Bacteriocin}

Bacteriocin sensitivity to physical conditions and chemical substances was also evaluated. Among ten bacteriocins CWL25 and GAL2 strains were identified as lipid containing bacteriocins because of their sensitivity to chloroform and boiling. These two bacteriocins were also inactivated by heating at $60^{\circ} \mathrm{C}$ for ten min. On the other hand the remaining strains were found to be resistant to chloroform and resistant to boiling for at least 10 minutes. These bacteriocins belong to low - molecular weight non-lipid containing bacteriocins. All the ten bacteriocins were stable between $\mathrm{pH} 4.5$ and 7.0 but sensitive to $\mathrm{pH}$ 9.0. Except for CWL25, BFL2, GAL2 and GAL3, strains the remaining strains were found to be active at $\mathrm{pH}$ 3.0. In acid neutralization test the inhibitory zones was determined around the wells of both the control (original culture supernatants) and buffered samples (buffered with $\mathrm{NaOH}$ ) (Table 8).

\subsubsection{Effect of $\mathrm{NaCl}$ on bacteriocin production}

The effect of $\mathrm{NaCl}$ on the production of the ten bacteriocin were studied. $1 \% \mathrm{NaCl}$ increased the production of bacteriocins in almost all strains. GAL1, BFL1 showed superior activity in presence of $3 \% \mathrm{NaCl}$ when compared to other isolates, but this activity was lost at $4 \% \mathrm{NaCl}$. CWL25 was inhibited by more than $1 \% \mathrm{NaCl}$ in $\mathrm{MRS}$ media and did not show any increase in their activity (Fig 1).

\subsubsection{Effect of incubation period on bacteriocin production}

The effect of incubation period at $37^{\circ} \mathrm{C}$ on bacteriocin production was also studied and it was observed that there was no growth after $15 \mathrm{hrs}$ of incubation and at the end of $24 \mathrm{hrs}$ the activity was found the maximum, while at 48 and $72 \mathrm{hrs}$ the inhibitory action was found to be comparatively less (Fig 2).

\subsubsection{Effect of different concentrations of carbon and nitrogen source on bacteriocin production}

The influence of culture medium components on the production of bacteriocin was investigated using Lactobacillus delbrueckii as an indicator organism. The result of this study revealed an increase in bacteriocin production in MRS medium containing 1\% glucose and 1\% peptone to normal MRS medium which was found to be optimum. Glucose was found to be better carbon source than lactose. It can be stated that variation in the concentration of constituents might have an influence on the amount of bacteriocin produced (Fig 3).

\section{Discussion}

Milk samples from cow, goat and buffalo were collected from different local areas of coimbatore and processed for isolation of LAB. The colonies from raw milk sample are expected to be little higher than real microflora. This is due to contamination from the animal, especially the exterior of the udder and the adjacent areas; bacteria found in manure, soil and water may enter (Garbutt, 1997).

From the tested samples hundred bacterial cultures were isolated to draw conclusion about the resident lactobacilli of the milk of particular cattle's. Lactobacillus was found higher in cow milk when compared to goat and buffalo milk. Singh and Rakesh Roshan Sharma (2009) have stated in their research that Leuconostoc and Lactobacillus both were found higher in number in camel milk as compared to cow, buffalo and goat milk. But the total number of bacteria was found higher in cow milk.

The LAB isolates were classified into the genera Lactobacillus based on their morphological and biochemical characters (Sharpe, 1979). Bacillary and cocci forms were positive to Gram reactions under a light microscope. In the present study, isolates were able to grow at $15^{\circ} \mathrm{C}$ and coccoid forms were not able to withstand $45^{\circ} \mathrm{C} . L$. alimentarius and L. animalis which are cocci in morphology were able to grow at $15^{\circ} \mathrm{C}$ but were not able to with stand at $45^{\circ} \mathrm{C}$ (Parvathy Seema Nair and Puthuvallil Kumaran Surendaran, 2005). Some Lactobacillus were found to be irregular, short, even coccoid rods with roun tappered ends, sometimes longer also (Kandler et al., 1983a). Few strains were able to utilize citrate and were found to be non motile; catalase, indole, MR-VP and citrate negative; nitrates are not reduced and gelatin was not liquefied. Isolated strains were homofermentative, fermenting glucose, lactose, sorbitol and mannitol. $41.6 \%$ of isolated strains were able to ferment sucrose and 21.6\% were able to ferment mannitol. Kandler and Weiss (1986) have classified Lactobacillus isolates from 
temperate regions according to their morphology, physiology and molecular characteristics. Coppolla et al. (2000) studied the morphological characters of raw milk, natural whey starter and cheese. De Man et al. (1960) stated that Lactobacilli are generally isolated on rich media such as MRS which is routinely used for the isolation and counting of Lactobacilli for most fermented food products. The addition of the reducing agent such as cysteine $(0.05 \%)$ to MRS improve the specificity of the medium for Lactobacillus isolation (Hetremink et al., 1997; Lankaputhra et al., 1995; Shah, 2000).

Lactobacillus plantarum, Lactobacillus lactis, Lactobacills fermentum and Lactobacillus casei were found in cow milk and Lactobacillus brevis and Lactobacillus delbrueckii were found in buffalo milk. Lactobacillus lactis, Lactobacills fermentum and Lactobacillus casei were found in goat milk. Lactobacillus lactis was dominating the Lactobacillus brevis in the buffalo milk sample. Similarly the same species was dominating the Lactobacillus fermentum, Lactobacillus casei and Lactobacillus delbrueckii in case of cow and goat milk sample also. Singh and Rakesh Roshan Sharma (2009) have stated that Lactobacillus fermentum and Lactobacillus casei were found in cow milk, Lactobacillus lactis, Lactobacillus acidophilus were found in buffalo milk sample.

In vitro assay was carried to characterize the antimicrobial potential of the culture supernatant to inhibit some pathogenic bacteria. Hundred LAB isolates were screened for bacteriocin producers by Agar spot assay test (Kilic et al., 1996). Isolates inhibiting the indicator organism by clear zone of inhibition were selected as bacteriocin producers. Total inhibition diameter was calculated for each LAB strain as the sum of the inhibition diameter against the indicator strain. The results of the Agar spot assay showed that a total of $10 \%$ of the isolates were able to inhibit the indicator organism by producing bacteriocin. Bacteriocin producers were found to be in a higher percentage of $12 \%$ from goat's milk when compared to the other cattle's milk. Nowroozil et al. (2004) has stated that antibacterial activities were done by an agar spot in which only $14.3 \%$ of strains made known to produce bacteriocin.

Active supernatants of Lactobacillus sp. were examined for acid and bacteriocin production; ten had inhibitory effects on sensitive bacteria including Lactobacillus strains and some common pathogenic bacteria. Among the bacteriocins tested, bacteriocins from BFL1 and GAL1 strains had a broader host range. It was observed that all the ten bacteriocins had an inhibitory effect on Bacillus mycoides, Klebsiella pnuemoniae, Staphylococcus aureus, Streptococcus faecalis and Proteus vulgaris were inhibited moderately. However, none of them affected Bacillus cereus, Bacillus amyloliquifaciens, Pseudomonas aeruginosa and Salmonella typhi. An expanded host range has been noted recently for a number of Lactobacillus bacteriocins, which kill E. faecalis, $L$. monocytogenes, C. botulinum, C. tyrobutyricum, S. aureus and A. hydrophila (Klaenhammer, 1993). Toba et al. (1991) determined bacteriocins in L. gasseri, L. acidophilus JCM 1132 and L. acidophilus LAPT 1060 strains from infant feces were active against other Lactobacillus strains.

The inhibitory effect was assumed to be due to bacteriocin not $\mathrm{H}_{2} \mathrm{O}_{2}$ since there was no oxidizing effect on bacterial cells which will destroy the basic molecular structure of cell proteins (Zsolt Zalan et al., 2005) and bacteriocin form the pores in the membrane of sensitive cells and deplete the transmembrane potential and/or the pH gradient, resulting in the leakage of cellular materials (Chikindas et al., 1993; McAuliffe et al., 2001).

Kanatani et al. (1995) has stated that a bacteriocin (acidocin A) from L. acidophilus TK9201 had inhibitory effect on closely related lactic acid bacteria and food borne pathogens including L. monocytogenes. Itoh et al. (1995) indicated that gassericin A produced by L. gasseri LA39 was one of the most active bacteriocins for use against enteric pathogens. Silva et al. (1987) isolated a low molecular weight substance from the Lactobacillus GC strain from the feaces of a healthy person with a potent inhibitory activity against a wide range of Gram positive and Gram negative bacteria.

Bacteriocin were characterized and tested for their in vitro antimicrobial activity against a group of organisms. The antimicrobial activities of bacteriocin producing isolates were differentiated from $\mathrm{pH} 3.0$ to 9.0 and $\mathrm{H}_{2} \mathrm{O}_{2}$ by standard methods. Bacteriocin isolated from CWL29, CWL1, CWL17, CWL6, BFL2, BFL1, GAL1 and GAL3, is considered to be resistant to chloroform and boiling. However the other two bacteriocin deserve for further study and all the bacteriocins characterized in this study were found to show antibacterial activity at a $\mathrm{pH}$ range of 4.0 to 7.0. Tagg et al. (1976) reported that most bacteriocins are resistant to acidic $\mathrm{pH}$ more than basic $\mathrm{pH}$. The inhibitory activity of the bacteriocin isolated from L. acidophilus LB strain occurred between $\mathrm{pH} 3.0$ and 5.0 and the inhibitory activity was lost when the $\mathrm{pH}$ was raised to 5.0-3.0 (Barefoot and Klaenhammer, 1984). Plantaricin S produced by L. plantarum LPCO10 showed inhibitory activity at $4 \% \mathrm{NaCl}$ (pH 3.0 to 7.0 ) (Diaz et al., 1993). Further more, it was observed from our present study that $1 \% \mathrm{NaCl}$ enhanced the bacteriocin production of all the ten bacteriocin isolates. Larsen et al. (1993) detected bavaricin A from L. bavaricus that showed no changes at $1 \% \mathrm{NaCl}$, but production was inhibited with increasing amount of $\mathrm{NaCl}$. It was stated that 
strains P1-001 and P8-002 from swine showed better tolerance at $4 \% \mathrm{NaCl}$, but not at $8 \% \mathrm{NaCl}$ when compared to the control (MRS), with characteristics of L. fermentum.

The effect of incubation period on bacteriocin production was also studied and it was observed that at the end of $48 \mathrm{hrs} \mathrm{pH}$ sensitivity test, the activity was found to be maximum. Further studies were carried out at different temperatures and $\mathrm{pH}$ sensitivity test of bacteriocin. The bacteriocins of all isolates were stable at $100^{\circ} \mathrm{C}$ for 10 minutes. The work carried out by Lade et al. (2006) has stated that bacteriocin isolates were stable at $100^{\circ} \mathrm{C}$ for $10 \mathrm{~min}$ and bacteriocin of Lactobacillus lactis was stable in acidic to neutral range i.e. from $\mathrm{pH} 4.0$ to 7.0 , but, inactive in the alkaline range. The result of our study revealed an increase in bacteriocin production in MRS medium containing $1 \%$ glucose and $1 \%$ peptone concentration. Glucose was found to be better carbon source than lactose. Thus, variation in the concentration of constituents might have an influence on the amount of bacteriocin produced. Ogunbanwo et al. (2003) obtained maximum bacteriocin production by supplementing $1 \%$ glucose and $1 \%$ peptone to normal MRS media. However it was observed from the present study that glucose and peptone gave better bacteriocin production. Lade et al. (2006) obtained maximum production by supplementing 3\% lactose and $2 \%$ peptone. Lactose was found to be better carbon source than glucose.

Viable Lactobacilli can inhibit food borne and enteric pathogenic microorganisms by producing lactic acid and other antimicrobial substances. Yogurt and acidophilus milk have been considered to be healthy probiotic diets (Eschenbach et al., 1989).

These studies have shown the isolates are defensive and they are been labeled as exceptional bacteria as they have shown their constructive role on human pathogens by inhibiting their growth for which they are said to be the second immune system of the body.

In conclusion the microbiota from milk is efficient in inhibiting the pathogenic organism and will act as a barrier by developing its antimicrobial activities in the host system of defense. The inhibitory spectrum of the antimicrobial substance has a potential application as a biopreservative in food industry. The occurrence of minority atypical resistance to certain antibiotics demonstrates that not all strains are suitable for use as probiotics or biotherapeutic agents. Spontaneous resistance nature of lactobacilli to a wide range of clinically important microorganism may enable the development of probiotic therapies for several infections and for the development of infant probiotic products.

\section{References}

Alpay, S., Aydin, F., Buruk, C.K. \& Kilic, A.O. (1991). Determination of antimicrobial effects of six bacteriocins isolated from vaginalis Lactobacillus. J Fac Pharm Gazi, 16(2), 63-68.

Alpay, S., Aydin, F., Buruk, C.K. \& Kilic, A.O. (2003). Antimicrobial activity and characteristics of bacteriocins produced by vaginal Lactobacilli. Turk. J. Med. Sci., 33, 7-13.

Barefoot, S.F. \& Klaenhammer, T.R. (1984). Purification and characterization of the Lactobacillus acidophilus bacteriocin lactacin B. Antimicrob. Agents Chemother, 26, 328-334.

Chikindas, M. L., Garcia-Garcera, M.J., Driessen, A.J., Ledeboer, A.M., Nissen-Meyer, J., Nes, I.F., Abee, T., Konings, W.N. \& Venema, G. (1993). Pediocin PA-1, a bacteriocin from Pediococcus acidilactici PAC1.0, forms hydrophilic pores in the cytoplasmic membrane of target cells. Appl. Environ. Microbiol, 59, 3577-3584.

Coeuret,V., Dubernet, S. \& Bernardeau., M. (2003). Isolation, characterization and identification of lactobacilli focusing mainly on cheeses and other dairy products. Lait., 83, 269-306.

Coppolla, R., Nanni, M., Iorizzo, M., Sorrentino, A., Sorrentino, E. \& Grazia, L. (2000). Survey of Lactic acid bacteria during the advanced stages of the ripening of Parmigiano reggiano cheese making and the first months of the ripening. Lait., 80, 479-490.

De Man, J.C., Rogosa, M. \& Sharpe, M.E. (1960). A medium for the cultivation of Lactobacilli. J. App. Bacteriol, 23,130-135.

Diaz, R., Sanchez, R.M.R., Desmazeud, M.., Ruiz-Barba, J.L. \& Piard, J.C. (1993). Plantaricin S and T, two new bacteriocins produced by Lactobacillus plantarum LPC010 isolated from a green olive fermentation. Appl. Environ. Microbiol, 59, 1416-1424.

Eshenbach, D. A., Davick, P.R., Williams, B.L., Klebanoff, S.J., Youngsmith, K., Critchlow, C.M. \& Holmes, K.K. (1989). Prevalence of hydrogen peroxide producing Lactobacillus species in normal women and women with bacterial vaginosis. J. Clin. Microbiol, 27, 251-256.

Garbutt. (1997). Essentials of Food Microbiology. Arnold International Edition. (pp. 67-72). 
Hetremink, R., Domenech, V.R. \& Rombouts, F.M. (1997). LAMVAB- A new selective medium for the isolation of Lactobaccilli form faeces. J. Microbiol. Meth, 29, 77-84.

Itoh, T., Fujimoto, Y., Kawai, Y., Toba, T. \& Saito, T. (1995). Inhibition of food-borne Pathogenic bacteria by bacteriocins from Lactobacillus gasseri. Lett. Appl. Microbiol, 21, 137-141.

Jack, R.W., Tagg, J.R. \& Ray, B. (1995). Bacteriocin of Gram positive bacteria. Microbiol. Rev, 59, 171-200.

Kandler, O., Schillinger, U. \& Weiss, N. (1983a). Lactobacillus halotolerans sp. Nov. nom. Rev. and Lactobacillus minor sp. Nov. nom. Rev. systematic Applied Microbiology, 4: 280-285.

Kandler, O. \& Weiss, N. (1986). Genus Lactobacillus beijerinck 1901. In Bergey's Manual of systematic Bacteriology, Vol 2. (p. 1209-1234).

Kanatani, K., Oshimura, M. \& Sano, K. (1995). Isolation and characterization of acidicin and cloning of the bacteriocin gene from Lactobacillus acidophilus. Appl. Environ, Microbiol, 61, 1061-1067.

Klaenhammer, T.R. (1993). Genetics of bacteriocins produced by lactic acid bacteria. FEMS. Microbiol. Rev., 12, 39-86.

Kilic, A.O., Pavlova, S.I., Ma, W. \& Tao, L. (1996). Analysis of Lactobacillus phages and bacteriocins in American dairy products and characterization of phages isolated from yogurt. Appl. Environ. Microbiol, 62, 2111-2116.

Lade, H.S., Chitanand, M.P., Gyananth, G. \& Kadam, T.A. (2006). Studies on some properties of Bacteriocins produced by Lactobacillus species Isolated from Agro-Based waste. Int. J. Microbiol, 2, 1.

Lankaputra, W. E. V. \& Shah, N.P. (1995). Survival of Lactobacillus acidophilus and Bifidobacterium sp., in the presence of acid and bile salts. Cult. Dairy. Prod. J., 30, 2-7.

Larsen, A.G., Vogensen, F.K. \& Josephsen, J.(1993). Antimicrobial activity of lactic acid bacteria isolated from sour doughs: purification and characterization of bavaricus M1401. J. Appl. Bacteriol, 75, 113-122.

McAuliffe, O., Ross, R.P. \& Hill, C. (2001). Lantibiotics: Structure, biosynthesis and mode of action. FEMS. Microbiol. Rev, 25, 285-308.

Nowroozi1, J., Mirzaii1, M. \& Norouzi, M. (2004). Study of Lactobacillus as Probiotic bacteria. Iranian. J. Publ. Health., 33(2): 1 -7.

Ogunbanwo, S.T., Sanni, A.I. \& Onilude, A.A. (2003). Influence of cultural conditions on the production of bacteriocin by Lactobacillus brevis OG1. African J. Biotechnol, 2(7), 179-184.

Parvathy Seema Nair \& Puthuvallil Kumaran Surendaran. (2005). Biochemical characterization of lactic acid bacteria isolated from fish and Prawm. Journal of culture collections, 4,48-52.

Piard, J.C. \& Desmazeaud, M. (1991). Inhibiting factors produced by lactic cid bacteria: 1. Oxygen metabolites and catabolism en-products. Lait., 71, 525-541.

Scannell, A.G.M. \& Ross, R.P., Hill, C. \& Arendt, E.K. (2000). An effective lacticin biopreservative in fresh pork sausage. J. Food. Prot., 63, 370-375.

Shah, N.P. (2000). Probiotic bacteria: Selective enumeration and survival in dairy food. J. Dairy. Sci., 83, 894-907.

Sharpe, M.E. (1979). Identification of the lactic acid bacteria. In: Skinner, F.A. Skinner and Lovelock, D.W. (Eds.), Identification methods for microbiologists. Soc. Appl. Bacteriol. Technical Series no. 14, Academic Press, London, (p. 246-255).

Silva, M., Jacobus, N.V., Deneke, C. \& Gorbach, S.L. (1987). Antimicrobial substance from a human Lactobacillus strain. Antimicrob. Agents. Chemother, 31, 1231-1233.

Singh, G.P. \& Rakesh Roshan Sharma. (2009). Dominating species of Lactobacilli and Leuconostocs present among the Lactic acid bacteria of milk of Different cattles. Asian J. Exp. Sci., 23(1), 173-179.

Tagg, J.R., Dajani, A.S. \& Wannamaker, L.W. (1976). Bacteriocins of gram-positive bacteria. Bacteriol. Rev., 40, $722-756$.

Toba, T., Samant, S.K. \& Itoh., T. (1991). Assay system for detecting bacteriocin in microdilution wells. Lett. Appl. Microbiol, 13, 102-104.

Zsolt Zalan, Edina Nemeth, Agnes Barath \& Anna Halasz. (2005). Influence of Growth Medium on Hydrogen Peroxide and Bacteriocin Production of Lactobacillus strains. Food Technol. Biotechno, 43 (3), 219-225. 
Table 1. Biochemical characterization of Lactobacillus isolated from cow milk

\begin{tabular}{|c|c|c|c|c|c|c|c|c|c|c|c|c|}
\hline \multirow{2}{*}{$\underset{n}{z}$} & \multirow{2}{*}{ 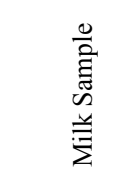 } & 苐 & \multirow{2}{*}{ 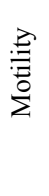 } & \multicolumn{2}{|c|}{ Growth } & \multirow{2}{*}{$\frac{\stackrel{0}{\circ}}{\frac{0}{\Xi}}$} & \multirow{2}{*}{$\mathfrak{\Sigma}$} & \multirow{2}{*}{$s$} & \multirow{2}{*}{ 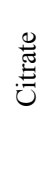 } & \multirow{2}{*}{ 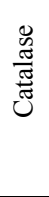 } & \multirow{2}{*}{ 莺 } & \multirow{2}{*}{$\begin{array}{l}\text { 志 } \\
\frac{\mathrm{J}}{\mathrm{S}} \\
\end{array}$} \\
\hline & & 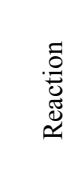 & & $15^{\circ} \mathrm{C}$ & $45^{\circ} \mathrm{C}$ & & & & & & & \\
\hline 1 & CWL1 & Rod & - & + & - & - & - & - & - & - & - & - \\
\hline 2 & CWL2 & Rod & - & + & - & - & - & - & - & - & - & - \\
\hline 3 & CWL3 & Rod & - & + & - & - & - & - & - & - & - & - \\
\hline 4 & CWL4 & $\mathrm{CB}$ & - & + & - & - & - & - & - & - & - & - \\
\hline 5 & CWL5 & Rod & - & + & - & - & - & - & - & - & - & - \\
\hline 6 & CWL6 & Rod & - & + & - & - & - & - & - & - & - & - \\
\hline 7 & CWL7 & Rod & - & + & - & - & - & - & - & - & - & \\
\hline 8 & CWL8 & Rod & - & + & - & - & - & - & - & - & - & - \\
\hline 9 & CWL9 & $\mathrm{CB}$ & - & + & - & - & - & - & - & - & - & - \\
\hline 10 & CWL10 & $\mathrm{CB}$ & - & + & - & - & - & - & - & - & - & - \\
\hline 11 & CWL11 & Rod & - & + & - & - & - & - & - & - & - & - \\
\hline 12 & CWL12 & Rod & - & + & - & - & - & - & - & - & - & - \\
\hline 13 & CWL13 & Rod & - & + & - & - & - & - & - & - & - & - \\
\hline 14 & CWL14 & Rod & - & + & - & - & - & - & - & - & - & - \\
\hline 15 & CWL15 & Rod & - & + & - & - & - & - & - & - & - & - \\
\hline 16 & CWL16 & $\mathrm{CB}$ & - & + & - & - & - & - & - & - & - & - \\
\hline 17 & CWL17 & Rod & - & + & - & - & - & - & - & - & - & - \\
\hline 18 & CWL18 & Rod & - & + & - & - & - & - & - & - & - & - \\
\hline 19 & CWL19 & Rod & - & + & - & - & - & - & - & - & - & - \\
\hline 20 & CWL20 & Rod & - & + & - & - & - & - & - & - & - & - \\
\hline 21 & CWL21 & Rod & - & + & - & - & - & - & - & - & - & - \\
\hline 22 & CWL22 & Rod & - & + & - & - & - & - & - & - & - & - \\
\hline 23 & CWL23 & Rod & - & + & - & - & - & - & - & - & - & - \\
\hline 24 & CWL24 & Rod & - & + & - & - & - & - & - & - & - & - \\
\hline 25 & CWL25 & $\mathrm{CB}$ & - & + & - & - & - & - & - & - & - & - \\
\hline 26 & CWL26 & Rod & - & + & - & - & - & - & - & - & - & - \\
\hline 27 & CWL27 & Rod & - & + & - & - & - & - & - & - & - & - \\
\hline 28 & CWL28 & Rod & - & + & - & - & - & - & - & - & - & - \\
\hline 29 & CWL29 & Rod & - & + & - & - & - & - & - & - & - & - \\
\hline 30 & CWL30 & Rod & - & + & - & - & - & - & - & - & - & - \\
\hline 31 & CWL31 & Rod & - & + & - & - & - & - & - & - & - & - \\
\hline 32 & CWL32 & Rod & - & + & - & - & - & - & - & - & - & - \\
\hline 33 & CWL33 & Rod & - & + & - & - & - & - & - & - & - & - \\
\hline 34 & CWL34 & Rod & - & + & - & - & - & - & - & - & - & - \\
\hline 35 & CWL35 & Rod & - & + & - & - & - & - & - & - & - & - \\
\hline 36 & CWL36 & Rod & - & + & - & - & - & - & - & - & - & - \\
\hline 37 & CWL37 & Rod & - & + & - & - & - & - & - & - & - & - \\
\hline 38 & CWL38 & Rod & - & + & - & - & - & - & - & - & - & - \\
\hline 39 & CWL39 & Rod & - & + & - & - & - & - & - & - & - & - \\
\hline 40 & CWL40 & Rod & - & + & - & - & - & - & - & - & - & - \\
\hline 41 & CWL41 & Rod & - & + & - & - & - & - & - & - & - & - \\
\hline 42 & CWL42 & Rod & - & + & - & - & - & - & - & - & - & - \\
\hline 43 & CWL43 & Rod & - & + & - & - & - & - & - & - & - & - \\
\hline 44 & CWL44 & Rod & - & + & - & - & - & - & - & - & - & - \\
\hline 45 & CWL45 & Rod & - & + & - & - & - & - & - & - & - & - \\
\hline 46 & CWL46 & Rod & - & + & - & - & - & - & - & - & - & - \\
\hline 47 & CWL47 & Rod & - & + & - & - & - & - & - & - & - & - \\
\hline 48 & CWL48 & Rod & - & + & - & - & - & - & - & - & - & - \\
\hline 49 & CWL49 & Rod & - & + & - & - & - & - & - & - & - & - \\
\hline 50 & CWL50 & Rod & - & + & - & - & - & - & - & - & - & - \\
\hline
\end{tabular}


Table 2. Biochemical characterization of Lactobacillus isolated from Buffalo Milk sample

\begin{tabular}{|c|c|c|c|c|c|c|c|c|c|c|c|c|c|c|}
\hline \multirow{2}{*}{$\underset{\dot{\Sigma}}{\stackrel{0}{0}}$} & \multirow{2}{*}{ 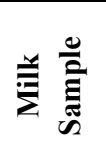 } & \multirow{2}{*}{ 衤 } & \multirow{2}{*}{ 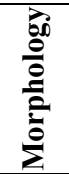 } & \multirow{2}{*}{ 宓导 } & \multirow{2}{*}{ 莺 } & \multicolumn{2}{|c|}{ Growth } & \multirow{2}{*}{$\begin{array}{l}\frac{\mathscr{O}}{0} \\
\stackrel{\Xi}{\Xi}\end{array}$} & \multirow{2}{*}{$\underline{\Sigma}$} & \multirow{2}{*}{$\hat{j}$} & \multirow{2}{*}{ ن } & \multirow{2}{*}{ ט. } & \multirow{2}{*}{ 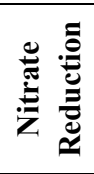 } & \multirow{2}{*}{ 先 } \\
\hline & & & & & & $15^{\circ} \mathrm{C}$ & $45^{\circ} \mathrm{C}$ & & & & & & & \\
\hline & \multirow{22}{*}{ Buffalo } & BFL1 & $\mathrm{CB}$ & + & - & + & - & - & - & - & - & - & - & - \\
\hline & & BFL2 & Rod & + & - & + & - & - & - & - & - & - & - & - \\
\hline & & BFL3 & Rod & + & - & + & - & - & - & - & - & - & - & - \\
\hline & & BFL4 & Rod & + & - & + & + & - & - & - & - & - & - & - \\
\hline & & BFL5 & Rod & + & - & + & + & - & - & - & - & - & - & - \\
\hline & & BFL6 & $\mathrm{CB}$ & + & - & + & - & - & - & - & - & - & - & - \\
\hline & & BFL7 & Rod & + & - & + & - & - & - & - & - & - & - & - \\
\hline & & BFL8 & Rod & + & - & + & - & - & - & - & - & - & - & - \\
\hline & & BFL9 & Rod & + & - & + & + & - & - & - & - & - & - & - \\
\hline & & BFL10 & Rod & + & - & + & & - & - & - & - & - & - & - \\
\hline & & BFL11 & Rod & + & - & + & + & - & - & - & + & - & - & - \\
\hline & & BFL12 & Rod & + & - & + & - & - & - & - & - & - & - & - \\
\hline & & BFL13 & $\mathrm{CB}$ & + & - & + & - & - & - & - & - & - & - & - \\
\hline & & BFL14 & Rod & + & - & + & - & - & - & - & - & - & - & - \\
\hline & & BFL15 & Rod & + & - & + & - & - & - & - & - & - & - & - \\
\hline & & BFL16 & Rod & + & - & + & - & - & - & - & - & - & - & - \\
\hline & & BFL17 & Rod & + & - & + & + & - & - & - & - & - & - & - \\
\hline & & BFL18 & $\mathrm{CB}$ & + & - & + & + & - & - & - & - & - & - & - \\
\hline & & BFL19 & Rod & + & - & + & + & - & - & - & - & - & - & - \\
\hline & & BFL20 & Rod & + & - & + & - & - & - & - & - & - & - & - \\
\hline & & BFL 21 & Rod & + & - & + & - & - & - & - & - & - & - & - \\
\hline & & BFL 22 & Rod & + & - & + & + & - & - & - & - & - & - & - \\
\hline
\end{tabular}


Table 3. Biochemical characterization of Lactobacillus isolated from Goat Milk sample

\begin{tabular}{|c|c|c|c|c|c|c|c|c|c|c|c|c|c|c|}
\hline \multirow{2}{*}{$\underset{\dot{n}}{\stackrel{8}{ }}$} & \multirow{2}{*}{ 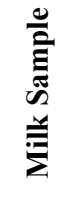 } & \multirow{2}{*}{ 施 } & \multirow{2}{*}{ 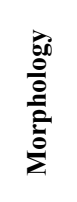 } & \multirow{2}{*}{ 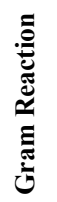 } & \multirow{2}{*}{ : } & \multicolumn{2}{|c|}{ Growth } & \multirow{2}{*}{$\frac{\stackrel{0}{0}}{\frac{O}{\Xi}}$} & \multirow{2}{*}{$\underline{\Sigma}$} & \multirow{2}{*}{$\hat{j}$} & \multirow{2}{*}{ 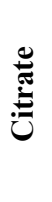 } & \multirow{2}{*}{ 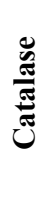 } & \multirow{2}{*}{ 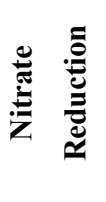 } & \multirow{2}{*}{ ש } \\
\hline & & & & & & $15^{\circ} \mathrm{C}$ & $45^{\circ} \mathrm{C}$ & & & & & & & \\
\hline 1. & \multirow{28}{*}{ Goat } & GAL1 & $\mathrm{CB}$ & + & - & + & + & - & - & - & - & - & - & - \\
\hline 2. & & GAL2 & Rod & + & - & + & + & - & - & - & - & - & - & - \\
\hline 3. & & GAL3 & Rod & + & - & + & + & - & - & - & - & - & - & - \\
\hline 4. & & GAL4 & Rod & + & - & + & + & - & - & - & - & - & - & - \\
\hline 5. & & GAL5 & Rod & + & - & + & - & - & - & - & - & - & - & - \\
\hline 6. & & GAL6 & Rod & + & - & + & - & - & - & - & - & - & - & - \\
\hline 7. & & GAL7 & Rod & + & - & + & - & - & - & - & - & - & - & - \\
\hline 8. & & GAL8 & Rod & + & - & + & + & - & - & - & - & - & - & - \\
\hline 9. & & GAL9 & Rod & + & - & + & + & - & - & - & - & - & - & - \\
\hline 10 & & GAL10 & Rod & + & - & + & - & - & - & - & - & - & - & - \\
\hline 11 & & GAL11 & Rod & + & - & + & - & - & - & - & - & - & - & - \\
\hline 12 & & GAL12 & Rod & + & - & + & - & - & - & - & - & - & - & - \\
\hline 13 & & GAL13 & Rod & + & - & + & + & - & - & - & - & - & - & - \\
\hline 14 & & GAL14 & Rod & + & - & + & + & - & - & - & - & - & - & - \\
\hline 15 & & GAL15 & Rod & + & - & + & + & - & - & - & - & - & - & - \\
\hline 16 & & GAL16 & Rod & + & - & + & - & - & - & - & + & - & - & - \\
\hline 17 & & GAL17 & Rod & + & - & + & - & - & - & - & - & - & - & - \\
\hline 18 & & GAL18 & Rod & + & - & + & - & - & - & - & - & - & - & - \\
\hline 19 & & GAL19 & $\mathrm{CB}$ & + & - & + & - & - & - & - & - & - & - & - \\
\hline 20 & & GAL20 & Rod & + & - & + & - & - & - & - & - & - & - & - \\
\hline 21 & & GAL21 & Rod & + & - & + & + & - & - & - & - & - & - & - \\
\hline 22 & & GAL22 & Rod & + & - & + & + & - & - & - & - & - & - & - \\
\hline 23 & & GAL23 & Rod & + & - & + & + & - & - & - & - & - & - & - \\
\hline 24 & & GAL24 & Rod & + & - & + & - & - & - & - & - & - & - & - \\
\hline 25 & & GAL25 & Rod & + & - & + & - & - & - & - & - & - & - & - \\
\hline 26 & & GAL26 & Rod & + & - & + & + & - & - & - & - & - & - & - \\
\hline 27 & & GAL27 & Rod & + & - & + & + & - & - & - & - & - & - & - \\
\hline 28 & & GAL28 & Rod & + & - & + & + & - & - & - & + & - & - & - \\
\hline
\end{tabular}


Table 4. Phenotypic profile of Lactobacillus from Cow milk sample

\begin{tabular}{|c|c|c|c|c|c|c|c|c|c|c|c|c|}
\hline $\begin{array}{l}\stackrel{\theta}{Z} \\
\dot{\boldsymbol{S}}\end{array}$ & 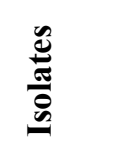 & $\frac{\mathscr{O}}{\stackrel{\Xi}{0}}$ & $\left\{\begin{array}{l}\frac{\tilde{o}}{0} \\
\overline{0} \\
\overline{0}\end{array}\right.$ & • & 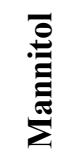 & : & : & 预 & 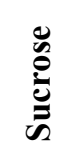 & 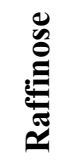 & 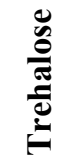 & 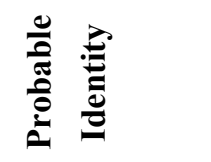 \\
\hline 1 & CWL1 & - & + & + & - & + & - & - & + & + & + & Lb.fermentum \\
\hline 2 & CWL2 & - & + & - & + & - & + & + & + & - & + & Lb.casei \\
\hline 3 & CWL3 & - & + & + & - & - & + & + & + & - & + & Lb.lactis \\
\hline 4 & CWL4 & - & + & + & - & - & + & + & + & - & + & Lb.lactis \\
\hline 5 & CWL5 & - & + & + & - & + & - & - & + & + & + & Lb.fermentum \\
\hline 6 & CWL6 & - & + & + & + & + & + & + & + & + & + & Lb.plantarum \\
\hline 7 & CWL7 & - & + & + & - & + & - & - & + & + & + & Lb.fermentum \\
\hline 8 & CWL8 & - & + & - & + & - & + & + & + & - & + & Lb.casei \\
\hline 9 & CWL9 & - & + & + & - & - & + & + & + & - & + & Lb.lactis \\
\hline 10 & CWL10 & - & + & + & - & - & + & + & + & - & + & Lb.lactis \\
\hline 11 & CWL11 & - & + & + & - & - & + & + & + & - & + & Lb.lactis \\
\hline 12 & CWL12 & - & + & + & - & + & - & - & + & + & + & Lb.fermentum \\
\hline 13 & CWL13 & - & + & + & - & + & - & - & + & + & + & Lb.fermentum \\
\hline 14 & CWL14 & - & + & - & + & - & + & + & + & - & + & Lb.casei \\
\hline 15 & CWL15 & - & + & + & - & + & - & - & + & + & + & Lb.fermentum \\
\hline 16 & CWL16 & - & + & + & - & - & + & + & + & - & + & Lb.lactis \\
\hline 17 & CWL17 & - & + & + & - & - & + & + & + & - & + & Lb.lactis \\
\hline 18 & CWL18 & - & + & + & - & + & - & - & + & + & + & Lb.fermentum \\
\hline 19 & CWL19 & - & + & + & - & + & - & - & + & + & + & Lb.fermentum \\
\hline 20 & CWL20 & - & + & - & + & - & + & + & + & - & + & Lb.casei \\
\hline 21 & CWL21 & - & + & + & - & - & + & + & + & - & + & Lb.lactis \\
\hline 22 & CWL22 & - & + & + & - & + & - & - & + & + & + & Lb.fermentum \\
\hline 23 & CWL23 & - & + & - & + & - & + & + & + & - & + & Lb.casei \\
\hline 24 & CWL24 & - & + & + & - & + & - & - & + & + & + & Lb.fermentum \\
\hline 25 & CWL25 & - & + & + & - & - & + & + & + & - & + & Lb.lactis \\
\hline 26 & CWL26 & - & + & - & + & - & + & + & + & - & + & Lb.casei \\
\hline 27 & CWL27 & - & + & - & + & - & + & + & + & - & + & Lb.casei \\
\hline 28 & CWL28 & - & + & - & + & - & + & + & + & - & + & Lb.casei \\
\hline 30 & CWL29 & - & + & - & + & - & + & + & + & - & + & Lb.casei \\
\hline 31 & CWL30 & - & + & + & - & - & + & + & + & - & + & Lb.lactis \\
\hline 32 & CWL31 & - & + & + & - & + & - & - & + & + & + & Lb.fermentum \\
\hline 33 & CWL32 & - & + & + & - & + & - & - & + & + & + & Lb.fermentum \\
\hline 34 & CWL33 & - & + & + & - & + & - & - & + & + & + & Lb.fermentum \\
\hline 35 & CWL34 & - & + & + & - & - & + & + & + & - & + & Lb.lactis \\
\hline 36 & CWL35 & - & + & + & - & - & + & + & + & - & + & Lb.lactis \\
\hline 37 & CWL36 & - & + & - & + & - & + & + & + & - & + & Lb.casei \\
\hline 38 & CWL37 & - & + & + & - & - & + & + & + & - & + & Lb.lactis \\
\hline 39 & CWL39 & - & + & - & + & - & + & + & + & - & + & Lb.casei \\
\hline 40 & CWL40 & - & + & + & - & - & + & + & + & - & + & Lb.lactis \\
\hline 41 & CWL41 & - & + & + & - & - & + & + & + & - & + & Lb.lactis \\
\hline 42 & CWL42 & - & + & + & - & - & + & + & + & - & + & Lb.lactis \\
\hline 43 & CWL43 & - & + & - & + & - & + & + & + & - & + & Lb.casei \\
\hline 44 & CWL44 & - & + & + & - & - & + & + & + & - & + & Lb.lactis \\
\hline 45 & CWL45 & - & + & + & - & - & + & + & + & - & + & Lb.lactis \\
\hline 46 & CWL46 & - & + & - & + & - & + & + & + & - & + & Lb.casei \\
\hline 47 & CWL47 & - & + & + & - & - & + & + & + & - & + & Lb.lactis \\
\hline 48 & CWL48 & - & + & + & - & - & + & + & + & - & + & Lb.lactis \\
\hline 49 & CWL49 & - & + & + & - & - & + & + & + & - & + & Lb.lactis \\
\hline 50 & CWL50 & - & + & - & + & - & + & + & + & - & + & Lb.casei \\
\hline
\end{tabular}


Table 5. Phenotypic profile of Lactobacillus from Buffalo milk sample

\begin{tabular}{|c|c|c|c|c|c|c|c|c|c|c|c|c|}
\hline$\underset{\infty}{\dot{z}}$ & 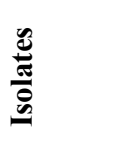 & 苋 & 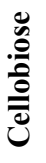 & 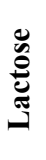 & 总 & 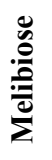 & 芯 & & 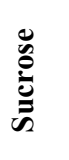 & 节 & 畩 & 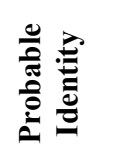 \\
\hline 1 & BFL1 & - & + & + & - & - & + & + & + & - & + & Lb.lactis \\
\hline 2 & BFL2 & - & + & + & - & - & + & + & + & - & + & Lb.lactis \\
\hline 3 & BFL3 & - & + & + & - & - & + & + & + & - & + & Lb.lactis \\
\hline 4 & BFL4 & - & + & + & - & - & + & + & + & - & + & Lb.lactis \\
\hline 5 & BFL5 & - & + & + & - & - & + & + & + & - & + & Lb.lactis \\
\hline 6 & BFL6 & - & + & + & - & - & + & + & + & - & + & Lb.lactis \\
\hline 7 & BFL7 & - & + & + & - & - & + & + & + & - & + & Lb.lactis \\
\hline 8 & BFL8 & - & + & + & - & - & + & + & + & - & + & Lb.lactis \\
\hline 9 & BFL9 & - & + & + & - & - & + & + & + & - & + & Lb.lactis \\
\hline 10 & BFL10 & - & + & + & - & - & + & + & + & - & + & Lb.lactis \\
\hline 11 & BFL11 & - & + & + & - & - & + & + & + & - & + & Lb.lactis \\
\hline 12 & BFL12 & + & - & - & + & - & + & - & + & + & - & Lb.brevis \\
\hline 13 & BFL13 & - & + & + & - & - & + & + & + & - & + & Lb.lactis \\
\hline 14 & BFL14 & - & + & + & - & - & + & + & + & - & + & Lb.lactis \\
\hline 15 & BFL15 & + & - & - & + & - & + & - & + & + & - & Lb.brevis \\
\hline 16 & BFL16 & + & - & - & + & - & + & - & + & + & - & Lb.brevis \\
\hline 17 & BFL17 & - & + & + & - & - & + & + & + & - & + & Lb.lactis \\
\hline 18 & BFL18 & - & + & + & - & - & + & + & + & - & + & Lb.lactis \\
\hline 19 & BFL19 & + & - & - & + & - & + & - & + & + & - & Lb.brevis \\
\hline 20 & BFL20 & + & - & - & + & - & + & - & + & + & - & Lb.brevis \\
\hline 21 & BFL 21 & - & + & + & - & - & + & + & + & - & + & Lb.lactis \\
\hline 22 & BFL 22 & - & + & + & - & - & + & + & + & - & + & Lb.lactis \\
\hline
\end{tabular}


Table 6. Phenotypic profile of Lactobacillus from Goat milk sample

\begin{tabular}{|c|c|c|c|c|c|c|c|c|c|c|c|c|}
\hline$\dot{z}_{i s}^{\dot{z}}$ & 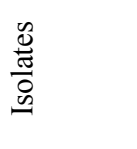 & 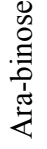 & $\begin{array}{l}0 \\
0 \\
0 \\
0 \\
0 \\
0 \\
0 \\
0\end{array}$ & 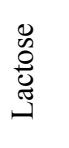 & $\begin{array}{l}\bar{o} \\
. \stackrel{0}{\Xi} \\
\stackrel{\Xi}{\Sigma}\end{array}$ & 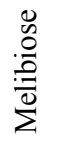 & 音 & 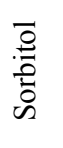 & $\begin{array}{l}0 \\
\infty \\
0 \\
\stackrel{0}{0} \\
\tilde{E}\end{array}$ & 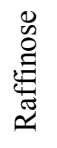 & 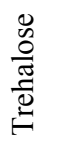 & 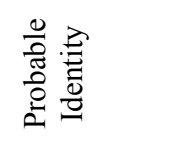 \\
\hline 23 & GAL1 & - & + & + & - & - & + & + & + & - & + & Lb.lactis \\
\hline 24 & GAL2 & - & + & + & - & + & - & - & + & + & + & Lb.fermentum \\
\hline 25 & GAL3 & - & + & + & - & - & + & + & + & - & + & Lb.lactis \\
\hline 26 & GAL4 & - & + & - & + & - & + & + & + & - & + & Lb.casei \\
\hline 27 & GAL5 & - & + & - & + & - & + & + & + & - & + & Lb.casei \\
\hline 28 & GAL6 & - & + & - & - & - & - & - & + & - & + & Lb.delbrueckil \\
\hline 30 & GAL7 & - & + & - & - & - & - & - & + & - & + & Lb.delbrueckil \\
\hline 31 & GAL8 & - & + & - & - & - & - & - & + & - & + & Lb.delbrueckil \\
\hline 32 & GAL9 & - & + & + & - & + & - & - & + & + & + & Lb.fermentum \\
\hline 33 & GAL10 & - & + & + & - & + & - & - & + & + & + & Lb.fermentum \\
\hline 34 & GAL11 & - & + & + & - & + & - & - & + & + & + & Lb.fermentum \\
\hline 35 & GAL12 & - & + & + & - & - & + & + & + & - & + & Lb.lactis \\
\hline 36 & GAL13 & - & + & + & - & - & + & + & + & - & + & Lb.lactis \\
\hline 37 & GAL14 & - & + & - & + & - & + & + & + & - & + & Lb.casei \\
\hline 38 & GAL15 & - & + & + & - & - & + & + & + & - & + & Lb.lactis \\
\hline 39 & GAL16 & - & + & - & + & - & + & + & + & - & + & Lb.casei \\
\hline 40 & GAL17 & - & + & - & - & - & - & - & + & - & + & Lb.delbrueckit \\
\hline 41 & GAL18 & - & + & - & - & - & - & - & + & - & + & Lb.delbrueckit \\
\hline 42 & GAL19 & - & + & + & - & - & + & + & + & - & + & Lb.lactis \\
\hline 43 & GAL20 & - & + & - & + & - & + & + & + & - & + & Lb.casei \\
\hline 44 & GAL21 & - & + & + & - & - & + & + & + & - & + & Lb.lactis \\
\hline 45 & GAL22 & - & + & + & - & - & + & + & + & - & + & Lb.lactis \\
\hline 46 & GAL23 & - & + & - & - & - & - & - & + & - & + & Lb.delbrueckil \\
\hline 47 & GAL24 & - & + & + & - & - & + & + & + & - & + & Lb.lactis \\
\hline 48 & GAL25 & - & + & + & - & - & + & + & + & - & + & Lb.lactis \\
\hline 49 & GAL26 & - & + & + & - & - & + & + & + & - & + & Lb.lactis \\
\hline 50 & GAL27 & - & + & - & - & - & - & - & + & - & + & Lb.delbrueckil \\
\hline
\end{tabular}


Table 7. Effect of Ten Bacteriocins on the growth of bacteria on Agar plates

\begin{tabular}{|c|c|c|c|c|c|c|c|c|c|c|}
\hline \multirow{2}{*}{ Indicator Strain } & & \multicolumn{6}{|c|}{ Bacteriocin Producing Lactobacillus strains } & \multirow[b]{2}{*}{$\sum^{3}$} & \multirow[b]{2}{*}{ 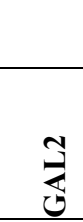 } & \multirow[b]{2}{*}{ 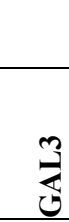 } \\
\hline & 3 & نْ & 3 & 先 & $\sum_{3}^{\stackrel{\text { సे }}{3}}$ & $\frac{3}{9}$ & $\stackrel{\mathcal{T}}{\mathcal{M}}$ & & & \\
\hline $\begin{array}{l}\text { Lactobacillus acidophilus } \\
\text { (MTCC 447) }\end{array}$ & VSI & VSI & VSI & VSI & VSI & VSI & VSI & VSI & VSI & VSI \\
\hline $\begin{array}{l}\text { Lactobacillus delbrueckii } \\
\text { subsp. lactis (MTCC 911) }\end{array}$ & VSI & SI & VSI & VSI & SI & VSI & SI & SI & VSI & SI \\
\hline $\begin{array}{l}\text { Lactococcus lactis } \\
\text { subsp.lactis (MTCC 440) }\end{array}$ & SI & VSI & SI & VSI & SI & VSI & VSI & SI & VSI & SI \\
\hline $\begin{array}{l}\text { Bacillus amyloliquifaciens } \\
\text { (MTCC 1270) }\end{array}$ & NI & NI & NI & NI & NI & NI & NI & NI & NI & NI \\
\hline $\begin{array}{l}\text { Bacillus cereus } \quad \text { (MTCC } \\
1272)\end{array}$ & NI & NI & NI & NI & $\mathrm{NI}$ & NI & NI & NI & NI & $\mathrm{NI}$ \\
\hline $\begin{array}{l}\text { Bacillus mycoides } \\
\text { (MTCC 645) }\end{array}$ & SI & SI & SI & SI & SI & VSI & SI & SI & VSI & SI \\
\hline $\begin{array}{l}\text { Klebsiella pnuemoniae } \\
\text { (MTCC 3384) }\end{array}$ & NI & SI & SI & SI & SI & VSI & NI & VSI & NI & NI \\
\hline $\begin{array}{l}\text { Staphylococcus aureus } \\
\text { (MTCC 740) }\end{array}$ & VSI & SI & VSI & VSI & VSI & VSI & MI & VSI & MI & MI \\
\hline $\begin{array}{l}\text { Streptococcus faecalis } \\
\text { (MTCC 459) }\end{array}$ & SI & VSI & VSI & VSI & VSI & VSI & SI & VSI & VSI & MI \\
\hline $\begin{array}{l}\text { Proteus vulgaris } \\
\text { (MTCC 744) }\end{array}$ & VSI & SI & SI & SI & SI & VSI & VSI & VSI & VSI & VSI \\
\hline $\begin{array}{l}\text { Psuedomonas aeruginosa } \\
\text { (MTCCC 647) }\end{array}$ & NI & NI & NI & NI & NI & NI & NI & NI & NI & $\mathrm{NI}$ \\
\hline $\begin{array}{l}\text { Salmonella typhi } \\
\text { (MTCC 531) }\end{array}$ & NI & NI & NI & NI & NI & NI & NI & NI & NI & $\mathrm{NI}$ \\
\hline
\end{tabular}

*CWL-Cow milk,Lactobacilli, BFL-Buffalo milk Lactobacilli, GAL- Goat milk Lactobacilli

Degree of inhibition: $\mathrm{MI}=$ Moderate inhibition Zone (6-9mm), SI = Strong inhibition Zone (10-14mm), VSI $=$ very strong inhibition Zone (15-18mm), NI =No inhibition zone. 
Table 8. Effects of chloroform, $\mathrm{pH}$ and heat treatment on bacteriocin of lactobacilli isolated from raw milk.

\begin{tabular}{|c|c|c|c|c|c|c|c|c|c|c|c|c|}
\hline \multirow[t]{2}{*}{$\begin{array}{c}\text { Bacteriocin } \\
\text { producing } \\
\text { Lactobacillus strains }\end{array}$} & \multirow[t]{2}{*}{$\begin{array}{c}\text { Sensitivity } \\
\text { to } \\
\text { chloroform }\end{array}$} & \multicolumn{4}{|c|}{$\begin{array}{c}\text { Resistance to } \\
\text { heating }(10 \mathrm{~min}) \\
\text { Temperature }\left({ }^{\circ} \mathrm{C}\right)\end{array}$} & \multicolumn{3}{|c|}{$\begin{array}{l}\text { Resistance to } \\
\text { boiling } 100^{\circ} \mathrm{C} \\
\text { (min) }\end{array}$} & \multicolumn{4}{|c|}{$\begin{array}{c}\text { Sensitivity to different } \\
\text { pH values }\end{array}$} \\
\hline & & 60 & 70 & 80 & 90 & 10 & 30 & 60 & 3.0 & 4.5 & 7.0 & 9.0 \\
\hline CWL1 & $\mathrm{R}$ & $\mathrm{R}$ & $\mathrm{R}$ & $\mathrm{R}$ & $\mathrm{R}$ & $\mathrm{R}$ & $\mathrm{S}$ & $\mathrm{S}$ & $\mathrm{R}$ & $\mathrm{R}$ & $\mathrm{R}$ & S \\
\hline CWL6 & $\mathrm{R}$ & $\mathrm{R}$ & $\mathrm{R}$ & $\mathrm{R}$ & $\mathrm{R}$ & $\mathrm{R}$ & $\mathrm{S}$ & $\mathrm{S}$ & $\mathrm{R}$ & $\mathrm{R}$ & $\mathrm{R}$ & S \\
\hline CWL17 & $\mathrm{R}$ & $\mathrm{R}$ & $\mathrm{R}$ & $\mathrm{R}$ & $\mathrm{R}$ & $\mathrm{R}$ & $\mathrm{S}$ & $\mathrm{S}$ & $\mathrm{R}$ & $\mathrm{R}$ & $\mathrm{R}$ & S \\
\hline CWL25 & S & S & $\mathrm{S}$ & $\mathrm{S}$ & S & $\mathrm{S}$ & $\mathrm{S}$ & $\mathrm{S}$ & S & $\mathrm{R}$ & $\mathrm{R}$ & S \\
\hline CWL29 & $\mathrm{R}$ & $\mathrm{R}$ & $\mathrm{S}$ & $\mathrm{S}$ & S & $\mathrm{R}$ & $\mathrm{S}$ & $\mathrm{S}$ & $\mathrm{R}$ & $\mathrm{R}$ & $\mathrm{R}$ & S \\
\hline BFLI & $\mathrm{R}$ & $\mathrm{R}$ & $\mathrm{R}$ & $\mathrm{R}$ & $\mathrm{R}$ & $\mathrm{R}$ & $\mathrm{S}$ & $\mathrm{S}$ & $\mathrm{R}$ & $\mathrm{R}$ & $\mathrm{R}$ & S \\
\hline BFL2 & $\mathrm{R}$ & $\mathrm{R}$ & $\mathrm{R}$ & $\mathrm{R}$ & $\mathrm{R}$ & $\mathrm{R}$ & $\mathrm{S}$ & $\mathrm{S}$ & $\mathrm{S}$ & $\mathrm{R}$ & $\mathrm{R}$ & $\mathrm{S}$ \\
\hline GAL1 & $\mathrm{R}$ & $\mathrm{R}$ & $\mathrm{R}$ & $\mathrm{R}$ & $\mathrm{R}$ & $\mathrm{R}$ & $\mathrm{S}$ & $\mathrm{S}$ & $\mathrm{R}$ & $\mathrm{R}$ & $\mathrm{R}$ & $\mathrm{S}$ \\
\hline GAL2 & S & S & $\mathrm{S}$ & $\mathrm{S}$ & S & S & $\mathrm{S}$ & $\mathrm{S}$ & S & $\mathrm{R}$ & $\mathrm{R}$ & $\mathrm{S}$ \\
\hline GAL3 & $\mathrm{R}$ & $\mathrm{R}$ & $\mathrm{R}$ & $\mathrm{R}$ & $\mathrm{R}$ & $\mathrm{R}$ & $\mathrm{S}$ & $\mathrm{S}$ & S & $\mathrm{R}$ & $\mathrm{R}$ & S \\
\hline
\end{tabular}

${ }^{*}$ CWL-Cow milk, Lactobacilli, BFL-Buffalo milk Lactobacilli, GAL- Goat milk Lactobacilli

$\mathrm{R}=$ Resistance $=$ Un inhibited bacteriocin activity, $\mathrm{S}=$ Sensitive $=$ Inhibited bacteriocin activity

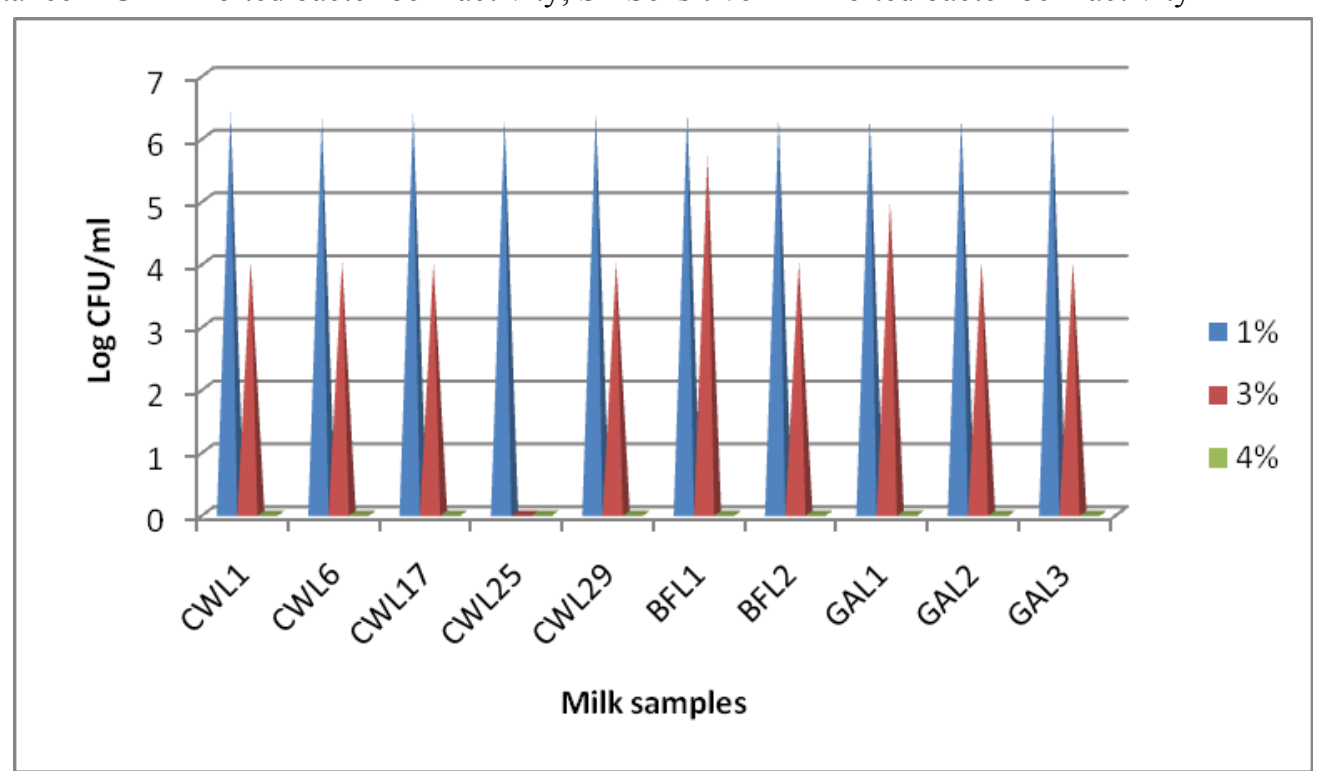

Figure 1. Effect of $\mathrm{NaCl}$ concentration on Bacteriocin production 


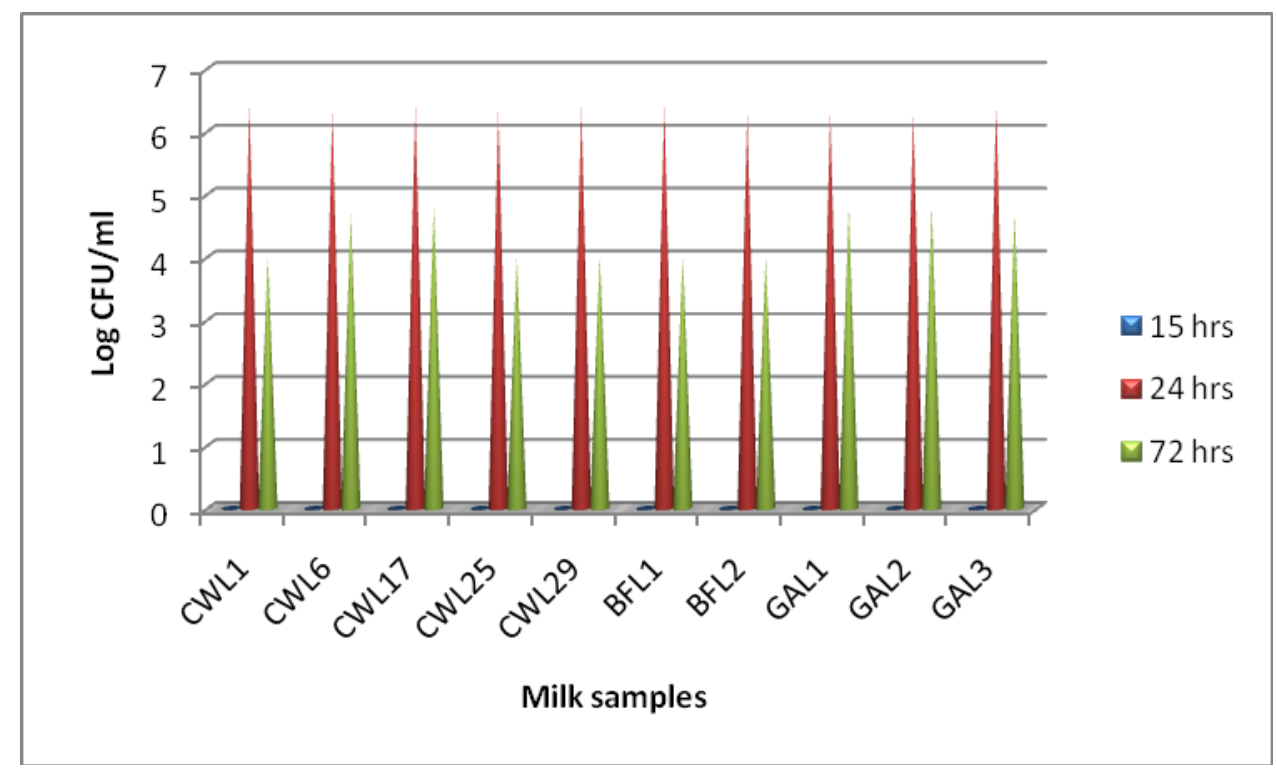

Figure 2. Effect of incubation period $\left(37^{\circ} \mathrm{C}\right)$ on Bacteriocin production

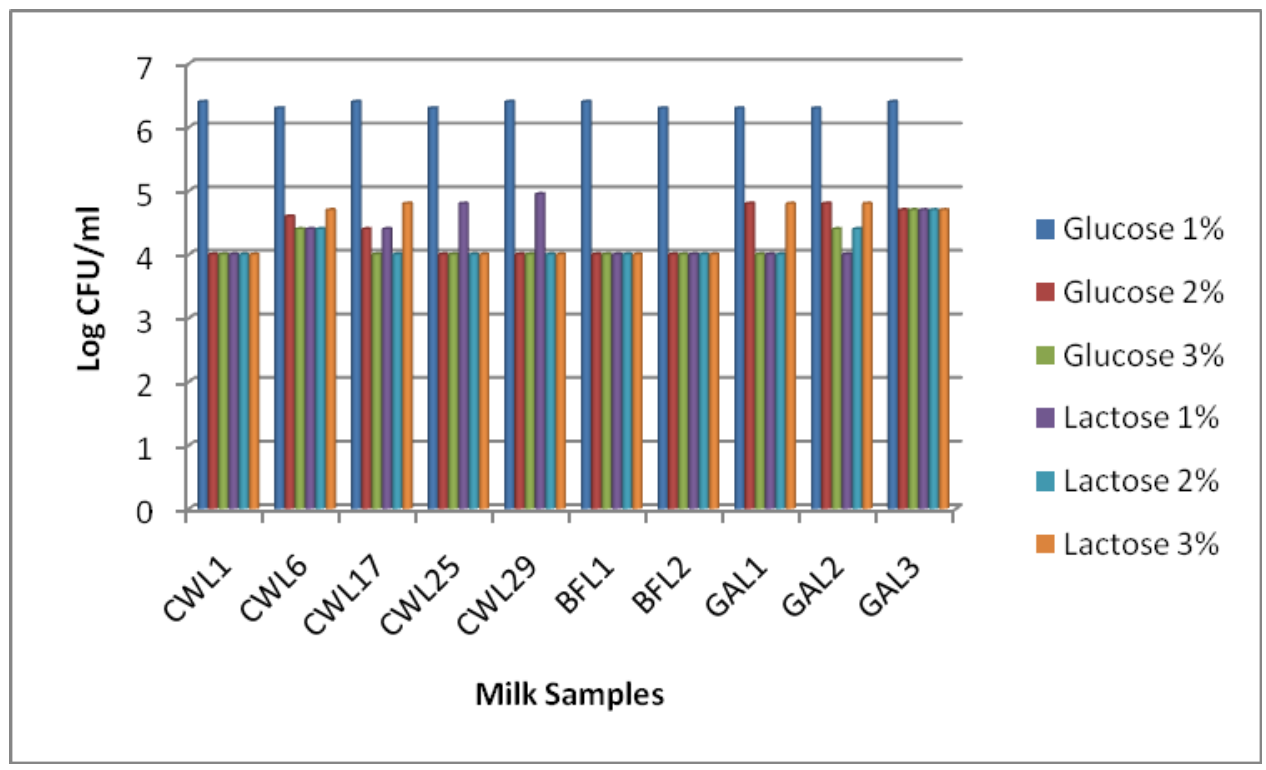

Figure 3. Effect of carbon sources on Bacteriocin production 